\title{
Aquaculture: a solution, or source of new problems?
}

Until recently, aquaculture - the selective breeding and raising of fish in 'fish farms' promised to resolve problems caused by the world's growing shortfall in marine fish supplies. But increasing awareness of its unwanted side-effects means that aquaculture itself is also heading for troubled waters, particularly in the developing countries.

Intensive fish farming in India and China, for example, the world's largest aquaculture producers, has led to pollution and the spread of disease. Evidence is also emerging that the promotion of aquaculture -84 per cent takes place in Asia - is causing significant unemployment among those engaged in traditional fishing.

Last month, India's Supreme Court dismissed a call for a judicial review of a decision last December demanding the closure of virtually all commercial shrimp farms in five coastal states by 15 April, and the payment of compensation to employees made redundant.

The decision includes a ban on all aquaculture in mangrove swamps, estuaries, wetlands, and on public land, as well as a prohibition on converting agricultural land into shrimp farms. The court had ordered the closure after a long campaign by environmentalist groups protesting in particular at the contamination of land and drinking water from the discharge of toxic effluent.

\section{Responsible for increased yield}

Despite growing problems, the United Nations' Food and Agriculture Organization (FAO) remains committed to its prediction that a 19 million-tonne shortfall in global fish supplies by 2010 will be filled by aquaculture. Aquaculture currently contributes just under one-fifth of world fish consumption, and is generally credited as being responsible for most of a 3 million-tonne increase in world fish consumption between 1990 and 1993.

Following FAO advice, and with the help of funding from the World Bank, most of Asia's leading fishing states have recently been taking major steps to develop aquaculture, which absorbs virtually all funding for fisheries research in Asian countries.

Aquaculture research in the Philippines, for example, received more than 80 per cent of fisheries research funding during the 1980s, according to Resource Allocation to Fisheries Research in Asia, a report published by the Asian Fisheries Society in Manila.

Aquaculture concentrates on three classes of fish: finfish, crustaceans and molluscs. Sixty per cent of production is in inland areas, with the rest along coastlines. And, rather than develop small-scale aquaculture for domestic consumption, countries have opted to invest heavily in intensive aquaculture for species such as shrimp, as a ready source of foreign exchange from exports.

Intensive aquaculture involves stocking vast ponds with large quantities of fish, food and chemicals. "To raise one tonne of shrimps requires 50 to 60 million litres of water," says Biksham Gujja, head of freshwater policy at the World Wide Fund for Nature in Geneva.

But this inevitably affects water supplies. Shrimp farms, for example, tend to be located near the coast; as a result, around 2.5 million cubic metres of effluent are discharged daily by farms on the east coast of India, adds Gujja. "This works out at about 15,000 litres

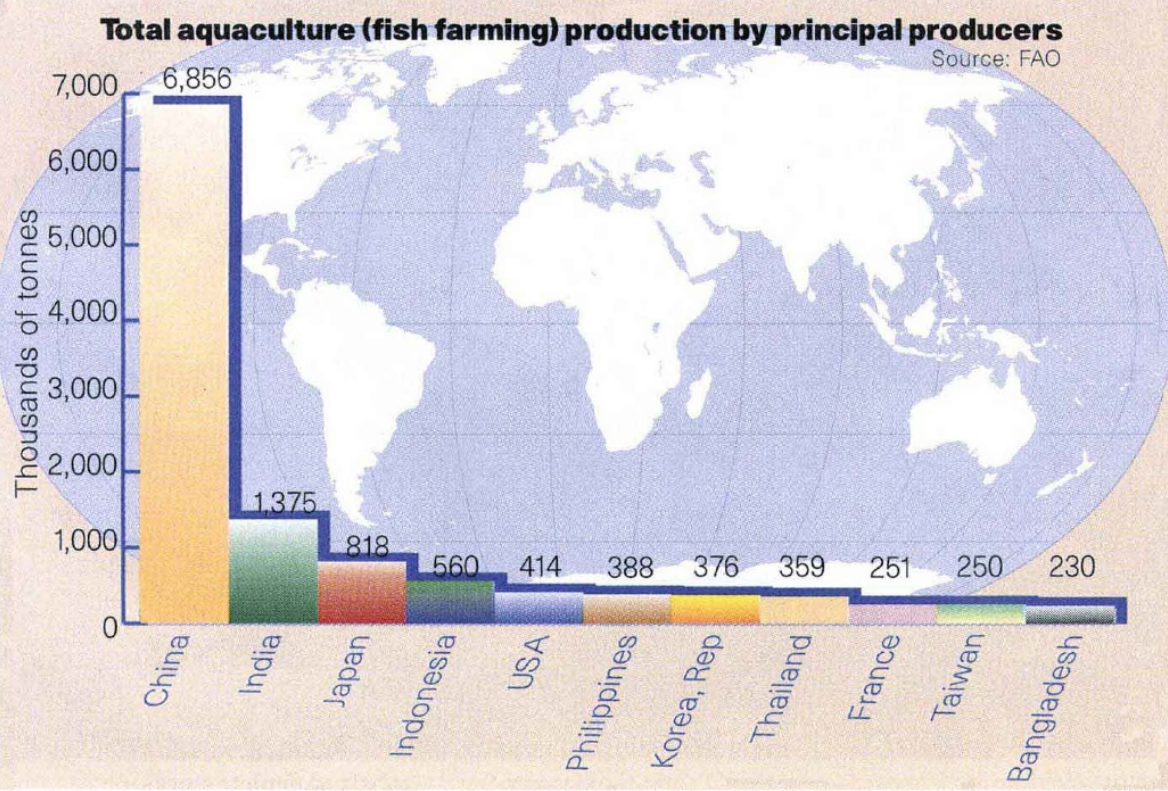

\section{IMAGE UNAVAILABLE FOR COPYRIGHT REASONS}

Paradise lost: prime paddy land in Thailand has been destroyed by pollution from shrimp farming.

\section{of effluent per kilogram of shrimp."}

Evidence presented by environmentalist groups at the Indian Supreme Court hearing showed that pollution from shrimp farms had affected drinking water, cropland, mangroves, groundwater aquifers and coastal fisheries. But whether such 'modest quantities' can meet the shortage in fish supplies remains to be seen.

One problem is the pressure that comes from a desire to seek quick profits. Malcolm Beveridge, head of the environment unit at the Institute of Aquaculture at the University of Stirling in Scotland, says many intensive shrimp farmers operate a 'flash and burn' policy by which farms are built, operated and abandoned within a short time.

\section{Operations being closed down}

Beveridge says that farm owners circumvent the disease problem by closing down their operations after four or five years and moving to a new location. "Thailand passed a law against this practice. But it doesn't seem to be working," he says.

Another concern is the impact on marine fishing from intensive aquaculture, particularly in countries where fishing by local communities is a direct source of food for families. "Aquaculture has a lot to offer," says Meryl Williams, director-general of the International Centre for Living Aquatic Resources Management in Manila. "But there needs to be a careful look at the winners and losers."

Beveridge believes that aquaculture can still make a significant contribution to fisheries production, providing it is done sustainably. Sustainable aquaculture, he says, is ideally performed inland, not near the coast. Also, it should use "only modest quantities of fertilizer [for the production of fish food], and water". 